\title{
The Impact of the Tourism Promotion-Mix Elements on the Foreign Tourists' Mental Images of the Jordanian Tourist Destinations (A Field Study)
}

\author{
Hameed Aldebi ${ }^{1}$, Noreyah Aljboory ${ }^{2}$ \\ ${ }^{1}$ Department of Marketing, College of Business, Al Zytoonah University of Jordan, Jordan \\ ${ }^{2}$ Department of Tourism Management, College of Business, Al Zytoonah University of Jordan, Jordan \\ Correspondence: Noreyah Aljboory, Department of Tourism Management, College of Business, Al Zytoonah \\ University of Jordan, Jordan.
}

Received: November 3, 2017

Accepted: November 28, 2017

Online Published: December 1, 2017

doi:10.5539/ibr.v11n1p74

URL: https://doi.org/10.5539/ibr.v11n1p74

\begin{abstract}
The present study aimed at identifying the impact of the tourism promotion-mix elements - which are represented in advertisement, publicity, public relations, personal selling, and sales promotion - on the foreign tourists' mental images of the Jordanian tourist destinations. Therefore, the sample of the present study was selected from Amman / Jordan and consisted from three hundred (300) foreign tourists. The tourism promotion-mix elements are considered independent variables and the foreign tourists' mental images of the Jordanian tourist destinations are considered a dependant variable. Several statistical methods were used to test the study's hypotheses and provide answers for the study's question.

It was concluded that the impacts of the tourism promotion-mix elements on the foreign tourists' mental images of the Jordanian tourist destinations vary. For instance, advertisement is the most influential promotion-mix element on the foreign tourists' mental images of the Jordanian tourist destinations. That is because it can interpret $47.4 \%$ of the change that occur in the dependant variable. However, sales promotion is the least influential promotion-mix element on the foreign tourists' mental images of the Jordanian tourist destinations. That is because it can interpret $29.1 \%$ of the change that occur in the dependant variable. It was concluded that there are statistically significant differences between the extents of influence of the tourism promotion-mix elements on the foreign tourists' mental images of the Jordanian tourist destinations which can be attributed to their nationality.

The researchers of the present study suggested several recommendations that can participate in enhancing and developing the Jordanian tourism sector. They also recommended providing more attention and care to the promotional activities that are based on social networking sites.
\end{abstract}

Keywords: the tourism promotion-mix elements, tourist destinations, mental image, Jordan

\section{Introduction}

The World Trade Organization $\left(\mathrm{WTO}^{1}\right)$ states - in its annual report of 2016 - that tourism involves several basic elements. The most prominent one is represented in people's movement from one site to another that is located outside their local community with seeking to visit a certain place called (the tourist destination). Such a destination includes various activities, experiences, facilities and services which aim at fulfilling the tourists' needs and motives. Such needs and motives have a social impact on the recipient societies and the societies that the tourists come from. It should be noted that such activities have a social nature and economic nature. The latter nature arises from the movement of foreign currencies to the tourist destination through tourists. In this context, it should be noted that the tourism promotion-mix elements - which are represented in advertisement, publicity, public relations, personal selling, and sales promotion - are considered very significant in attracting tourists and convincing them to visit the tourist attractions that possess requirements of tourist attraction. Such requirements may include: mountains, rivers, beaches, seas, lakes, waterfalls, suitable climate, snow, and cultural and religious landmarks. Such requirements are considered natural elements of attraction created by God to provide humans with. Requirements of tourist attraction also include requirements related to tourist secondary or complementary offers, such as hotels, restaurants, airports, and tourist villages, complexes, and camps. 
Based on the aforementioned, Jordan has a variety of the requirements of tourist attraction. Such requirements made Jordan a new tourist attraction on the world map of tourism. For instance, Jordan is a tourist attraction for the ones seeking cruise tourism. Aqaba and the Dead Sea are considered tourist attractions for the ones seeking this kind of tourism. Jordan is also a tourist attraction for the ones seeking desert and adventure tourism. Wadi Ram represents a tourist attraction for the ones seeking these types of tourism. Jordan is a tourist attraction for the ones seeking archaeological and cultural tourism. Petra and Jarash are considered tourist attractions for the ones seeking these kinds of tourism. Jordan is also a tourist attraction for the ones seeking medic al tourism. That is because Jordan includes many hospitals that have obtained international accreditation in the field of health services. To add more, Jordan is also a tourist attraction for the ones seeking accommodation, entertainment, and catering services. For instance, Amman includes fourteen (14) chain hotels ${ }^{2}$. In 2016, the capacity of those hotels is greater than five thousand (5000) beds. In this context, the current study aims at creating interaction and a complementary relationship between a group of tourism services and the requirements of tourist attraction which the tourist desire to visit, see, enjoy and benefit from them. Based on the aforementioned, the present study aims at exploring and analysing the tourism promotion-mix elements and their impact on the foreign tourists' images towards the Jordanian tourist destinations.

'WTO: World Tourism Organization, Annual report, 2016, Madrid

2The Ministry of Tourism and Antiquities, Jordan Tourism Board, 2017

\subsection{Statement of the Problem}

The study's problem is represented in the following questions:

1) Do the foreign tourists have adequate understanding and awareness when recognizing and assessing the tourism promotion-mix elements - which are represented in (advertisement, publicity, public relations, personal selling, and sales promotion)?

2) Do the foreign tourists' evaluations for the tourism promotion-mix elements vary with the variation of the demographic variables, such as: the nationality?

3) Do the foreign tourists' evaluations for the (Jordanian) tourist attractions vary?

4) Which element of the tourism promotion-mix elements is considered the most influential one on the foreign tourists' mental images of the Jordanian tourist destinations?

5) Do the advertisement and publicity have a negative or positive impact on the foreign tourists' choice of Jordan as a tourist destination?

6) Do the public relations have an impact on the foreign tourists' choice of Jordan as a tourist destination?

7) Do personal selling and sales promotion have a positive impact on the foreign tourists' choice of Jordan as a tourist destination?

8) Do the foreign tourists feel satisfied about the tourist destinations they have visited during their stay in Jordan?

\subsection{The Study's Objectives}

The present study aims at achieving the following:

1) Identifying the impact of the tourism promotion-mix elements - which are represented in advertisement, publicity, public relations, personal selling, and sales promotion - on the foreign tourists' mental images of the Jordanian tourist destinations

2) Identifying the foreign tourists' attitudes towards the Jordanian tourist destinations

3) Identifying the most influential promotion-mix element on attracting the foreign tourists towards the Jordanian tourist destinations they would like to visit

4) Measuring the satisfaction level of the foreign tourists about the services provided by the tourist destinations during their stay or visit in Jordan 


\subsection{The Study's Model}

Independent Variables
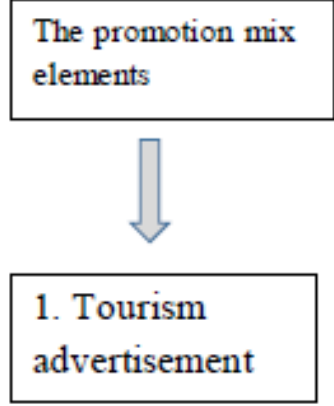

2)- Tourism
publicity

3)- Tourism
public relations

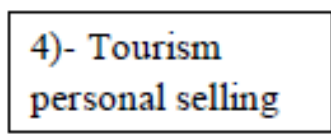

$$
\begin{aligned}
& \text { 5)- Tourism } \\
& \text { ssales promotion }
\end{aligned}
$$

dependent Variable

The foreign tourist's' mental image of the tourist destination

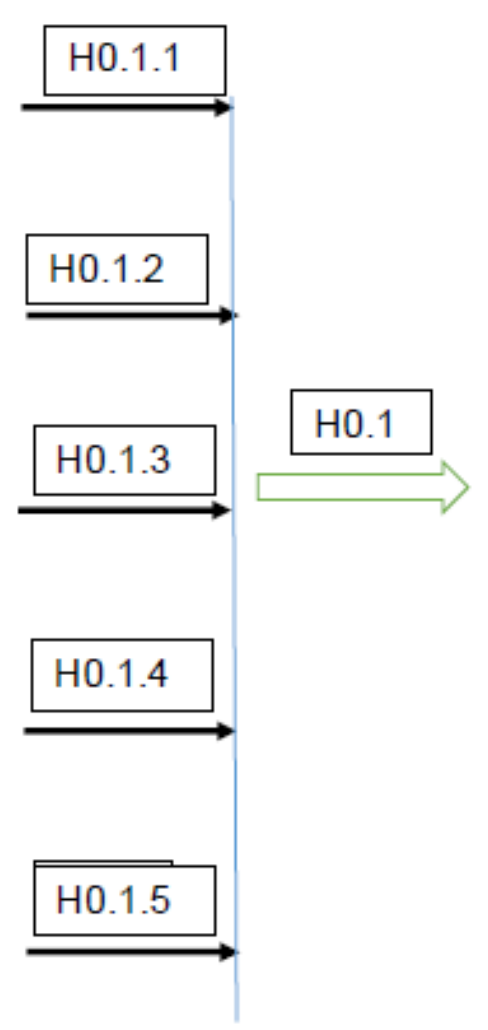

\begin{tabular}{|l|}
\hline Previous experiences \\
\hline Quality of the provided services \\
\hline $\begin{array}{l}\text { Authenticity and having a } \\
\text { distinguished tourist site }\end{array}$ \\
\hline Uniqueness \\
Reputation of the tourist destination \\
in comparison to the reputations of \\
the other competitive tourist \\
destinations in the tourism market \\
on the Arab and global level
\end{tabular}

Figure 1. The Study's Model

*The study's model was designed based on the relevant previous studies that were reviewed by the researchers of the present study

\subsection{The Study's Hypotheses}

The study's hypotheses are the following:

The first hypothesis: There isn't any statistically significant relationship at the significance level $0.05 \geq$ a between the tourism promotion-mix elements as a whole - which are represented in advertisement, publicity, public relations, personal selling, and sales promotion - and the foreign tourists' mental images of the Jordanian tourist destinations

\section{The following sub- hypotheses are derived from the aforementioned hypothesis :}

The First sub-hypothesis: There isn't any statistically significant relationship - at the significance level $0.05 \geq a$ - between advertisement and the foreign tourists' mental images of the Jordanian tourist destinations.

The Second sub-hypothesis: There isn't any statistically significant relationship - at the significance level 0.05 $\geq \mathrm{a}$ - between publicity and the foreign tourists' mental images of the Jordanian tourist destinations

The Third sub-hypothesis: There isn't any statistically significant relationship - at the significance level $0.05 \geq$ a - between public relations and the foreign tourists' mental images of the Jordanian tourist destinations

The Fourth sub-hypothesis: There isn't any statistically significant relationship - at the significance level 0.05 $\geq \mathrm{a}$ - between personal selling and the foreign tourists' mental images of the Jordanian tourist destinations 
The Fifth sub-hypothesis: There isn’t any statistically significant relationship - at the significance level $0.05 \geq a$ - between sales promotion and the foreign tourists' mental images of the Jordanian tourist destinations

The Second Hypothesis: There isn't any statistically significant difference - at the significance level $0.05 \geq a$ between the extent of influence of the tourism promotion-mix elements on the foreign tourists' mental images of the Jordanian tourist destinations which can be attributed to their nationality

\subsection{The Study's Methodology}

The researchers of the present study distributed four hundred (400) questionnaire forms in Amman / Jordan. However, three hundred fifty five (355) questionnaire forms were retrieved. The numbers of the distributed and retrieved questionnaire forms are presented in the table below:

\begin{tabular}{ccccc}
\hline Nationality & $\begin{array}{c}\text { The distributed } \\
\text { questionnaire forms }\end{array}$ & $\begin{array}{c}\text { The retrieved questionnaire } \\
\text { forms }\end{array}$ & $\begin{array}{c}\text { Response } \\
\text { rate }\end{array}$ & Sample \\
\hline American & 110 & 100 & 90.9 & 90 \\
British & 80 & 70 & 87.5 & 60 \\
French & 80 & 80 & $\% 100$ & 70 \\
German & 30 & 25 & 83.3 & 20 \\
Canadian & 50 & 40 & 80 & 30 \\
Italian & 50 & 40 & 80 & 30 \\
Total & 400 & 355 & 88.8 & 300 \\
\hline
\end{tabular}

Three hundred fifty five (355) questionnaire forms were retrieved out of four hundred (400) questionnaire forms. The response rate is $88.8 \%$. As for the questionnaire forms that are considered valid for statistical analysis, they include three hundred (300) questionnaire forms.

The process of distributing the questionnaire forms took four months; June, July, August and September. This process was carried out in 2016. The sample included the foreign tourists visiting Jordan during the time of conducting the study.

\section{The Theoretical Framework of the Study}

\subsection{Development of the Tourist Attractions}

Tourism experts - including (William 2002, Annamira et.al, 2017, Yeam duan et.al, 2017) - state that the first step towards developing the tourist attractions is represented in inventorying these areas on ground in a comprehensive manner. That means that the government should count the number of the tourist attractions that actually exist in a certain country, province or region.

After finishing the inventory process, the differences between the tourist attractions require assessing all the potential and current tourist attractions that were covered by the inventory. Such assessment must be based on five standards; (quality, authenticity, uniqueness, activity expansion, and attractiveness power). They are illustrated below:

1) Quality: Quality can make the tourists feel fully satisfied about the tourist attractions they visit. To be specific, high quality is achieved when the performance of the tourist attractions' services surpasses the expectations of the tourists.

2) Authenticity: It allows people to have sense of place. Authenticity doesn't involve tangible aspects only, but involves intangible ones. An example on authenticity is the spiritual authenticity which exists in holy and religious places.

3) Uniqueness: It is represented in providing distinguished services and having a place that is characterized with being unique on the global level. In other words, to consider the place as unique, it must be considered as something new by the tourist, make his feelings move and feels the highest levels of satisfaction about it.

Examples of unique tourist attractions can include Petra, the Dead Sea and Al-Maghtas (the Baptism site). These tourist attractions are considered unique on the global level.

4) Activity expansion: Tourists do not visit tourist attraction to watch the spectacular views only. In fact, they visit such places to do certain activities that fulfill their desires and needs. Such activities may include: playing sports, and attending conferences, parties, festivals, parties and cultural celebrations.

5) Attractiveness power: It is measured by the number of the ones visiting the concerned place, the duration of their stay, the distance travelled to arrive at the it and the means of transportation used for travelling to arrive at it (it may be by sea, air or land). 
In this context, it should be noted that conducting a feasibility study about the tourist attraction is considered something necessary. That is because such a study enables one to identify the strengths weaknesses, and opportunities of the tourist attraction and the threats facing it. That is abbreviated as the (SWOT matrix)( schmoll 2010).

\subsection{The Marketing Mix of the Tourist Attractions}

The World Trade Organization (WTO) - in its annual report of 2017- and the experts in world tourism state that more attention should be provided for the current tourist attractions. They also state that there must be more efforts exerted for achieving sustainable tourism development and enchanting the potential tourist attractions. They also state that new methods must be found for promoting tourism in the potential tourist attractions, attracting tourists to visit them, and make tourists benefit from the services provided in those places.

In line with the aforementioned, Kotler et al. (2014), ( saritha, 2013, Markino, 2012, Michele 2013) state that it is necessary to activate the role of the marketing mix in enhancing the tourist attractions. Such an activation is represented in the following:

1) Providing suitable services in the concerned tourist attraction.

2) Assigning appropriate reasonable prices to the offered services that are consistent with the financial capacity of the tourists who benefit from those services. In addition, a state of balance must be achieved between the quality of the tourist services and their prices.

3) Creating a promotional communication network that can achieve an effective communication that doesn't cover the tourist attractions and tourists only, but also covers the business tourism organizations and service providers. That is called (the internal marketing promotion). Advertisement, publicity, public relations and sales promotion are all considered essential elements in the tourism promotion structure. It should be noted that the tourism promotion is a persuasive communication process that aims at persuading and attracting the tourist to make the purchasing decision that is represented in visiting the tourist country. The expression (tourism promotion mix) refers to a group of elements that interact with each other and complement one another to achieve the promotional goals of the business tourism organizations within the framework of the dominant promotional ideology. Such business tourism organizations include hotels, restaurants, travel and tourism offices, and airline companies

4) Using appropriate distribution channels which refer to all the direct and indirect channels that facilitate the arrival of the tourist to the tourist attraction. Such channel may include: the travel and tourism agencies, tourist guides, and road, air and maritime transport companies. Such channels also include tourism websites, internet, social networking sites, like Facebook, Twitter, WhatsApp, etc... (Al-taee and Ahmed 2010)

Tourism promotion is characterized with a unique human touch. That is because tourism services require the intervention of humans who deal with tourists as people seeking pleasure, authenticity, and innovation. That is why tourism promotion is called (creative promotion). (Al-taee and Al-alak 2012) DMA2000 states that in order for the tourism promotion to be effective, there are certain elements that must be available in it. These elements are:

A. A clear vision and identifying the targeted category of people.

B. Easy access to the required information, provided that such information must be accurate, clear, documented, updated, and useful for tourists

C. Showing creativity and innovation in wording the promotional message and in the way it is delivered to the targeted category of people.

D. Adhering to ethics and avoiding exaggeration in advertisement. Such elements also include avoiding providing disinformation and deception in the processes of delivering and presenting information

5) Service providers represent a key element among the marketing mix elements. For instance, their failure in providing the tourist services shall make the other elements useless.

That requires from the business tourism organizations - such as: hotels, restaurants, and travel and tourism agencies - to look for efficient and skilled workers who have adequate experience in this vital sector. Tourism experts believe that service providers are considered an essential vital part of any tourism product.

6) The process of delivering services: This element is directly connected with the previous element and complements it. The tourist service is provided through the use of certain methods and techniques under certain agreed upon procedures that should not be violated or make any discretionary opinion about them. 
The process of delivering the service involves intangible aspects, such as: sympathizing with the tourists, understating their conditions, the way of satisfying them, solving their problems, welcoming them, and the taking care of them as people with delicate emotions and feelings.

7) The physical environment: There is no doubt that tourist's visit the tourist attraction because it includes things that they desire to see and enjoy and benefit from the intangible services that are in such places. Regardless of how good these services are, they are useless without having a physical environment that the tourist recognizes and interacts with it. For instance, the furniture, decorations, heating and cooling system, attractive colors, oil paintings, flowers, trees, and perfumes can turn the intangible aspects of the tourist service into perceptible and useful tangible aspects.

\subsection{The Mind Image Concept}

(Kotler et.al. 2014 and love lock et.al. 2014) states that mind image refers to the overall beliefs, impressions, ideas, and perceptions that people have about things, behaviors and e vents. As for Kotler (2000), he believes that mental image refers to the product of accumulated exceptions. The researchers of the present study define mental image as being perceptions and expectations that are formed within the tourists' mind who visit the tourist attraction generated from experiences, practices, information, and the word of mouth.

(William G. 2002) is a prominent figure among the ones who provided definitions for the mental image concept. For instance, the latter defines mental image as being the feelings that people carry for any perceptible thing. This definition is considered the most popular and acceptable definition among the definitions of mental image. The latter researcher believes that mental image involves certain elements, and concepts, such as: attitude, behavior, and motives. The attitude is an acquired mental state towards people, events or situations with some degree of positivity or negativity. As for behavior, it is represented in one's response for some external stimuli. Attitudes depend on the situation and are considered the product of motives that drive someone to commit a certain act or behavior. As for motives, they refer to a group of stimuli. To be more specific, motives refer to the arousal of interest. These concepts together constitute the mental image.

The World Trade Organization (WTO) states that the tourist's mental image represents one single aspect only of the whole general image formed about the hosting or tourism country even if both images are strongly overlapped. It is unlikely to see the tourist visiting a tourist country that a negative mental image for. Therefore, the tourist's exploration for a certain country shall lead him to identify the economic, cultural or political aspects of that country. The mental image consists from several levels, which are: (Al-Taee, and Al-alak, 2010)

1) The organic image: It refers to the image formed as a result of receiving information that is managed in an organized or programmed manner by the hosting country or the country of destination. Such information can be found in historical or geographical books.

2) The induced image: This image is formed within one's mind as a result of programed and organized promotional efforts that are exerted by trip organizers, travel agencies, or the official bodies in the hosting country. Hence, it is necessary to distinguish between those two levels. That is because the induced mental image can be controlled, whereas the organic mental image is difficult to be controlled by marketers, and promoters. Based on the aforementioned, the present study aimed at shedding a light on the induced mental image. The latter image can be controlled and its mechanisms can be handled in a scientific manner that ensures producing useful results that shall be reflected positively on the tourism destinations and the tourism country.

\subsection{Components of the Mental Image}

The mental image that the tourist has of the tourism destination consists from three overlapped hierarchical components which are identified below:

1) The cognitive component

2) The affective component

3) The voluntary component

These elements lead the tourist to make the decision of travelling to the concerned tourist destination that he desires to visit during his next or coming trip.

Scott (1965) defines the cognitive mental image component as being an evaluation made for the characteristics that are commonly known by people. It can be also defined as being the smart perception for the product. To illustrate more, it can be noticed that there are many global tourist cities that people have created mental images for due to external stimuli. The mental images created for Paris are represented in being the city of the Eiffel 
tower, perfumes, and beauty. People have created mental images for Rome as being the city of history and roman antiquities, Petra as the being the Pink City and the Dead Sea as being the lowest point in the world and not having any sea animals, fish, birds alive in it.

As for the affective mental image component, it is connected with one's motives. In this context, this component refers to the way in which the individual evaluates a certain matter. In other words, it refers to the emotions that one carries for a certain matter or subject.

As for the third mental image component (i.e. the voluntary component), it is considered equivalent for behavior because it represents the act component. After processing the external and internal stimuli of the tourist destination, the decision of visiting it or not shall be made. This decision represents the voluntary mental image component. This component is directly connected with the other two components. That is because the third component depends on the mental image that was formed during the cognitive mental image formation and assessed during the affective mental image stage. All these three elements together constitute the process of making this decision.

The tourism marketing experts state that there are six essential requirements that must be available for establishing a positive image among the local and foreign tourists for any tourist attraction whether it is a region, city, or province. These six requirements are identified below:

1) Natural and cultural requirements of attraction (mountains, rivers, seas, archaeology, etc...)

2) Requirements of attraction related to the easiness of arrival, and the availability of comfortable safe means of transportation for the tourists

3) Catering and accommodation requirements, such as: hotels and restaurants.

4) Requirements related to activities, entertainment, gym, stadium, etc..

5) Requirements related to safety, organization and hygiene

6) Requirements related to complementary and additional services, such as: banks, hospitals, means of communication, mail, etc...

\subsection{Previous Studies}

1) Brees, Ahmad \& Al-Hamiri Bashar (2014). The impact of the promotional-mix of tourist services on achieving satisfaction among tourists: A field study in tourist facilities in Karbala'/ Iraq.

The latter researchers concluded that the tourists visiting Karbala' are satisfied about the services provided to them. It was concluded that the promotional mix elements - represented in advertisement, publicity, public relations, personal selling, and sales promotion - have a positive impact on achieving satisfaction among the tourists. In the latter study, personal selling is ranked first ( $82 \%)$, followed by advertisement, and publicity $(64 \%)$. Sales promotion is ranked last $(20 \%)$. That mean that the latter element is the least influential one.

2) Al-Hadid and Al-Shunaq (2013): The impact of the electronic marketing mix on tourists' attitudes towards tourism in Jordan.

The study concluded that electronic marketing dimensions vary in their extent of influence on tourists' attitudes towards tourism in Jordan. The accuracy of the information is considered the most influential element $(\mathrm{B}=0.4 .20)$ followed by price (0.270).

3) Al-Rabi'a (2007): The impact of using internet on promoting tourism in the United Arab Emirates (UAE). The study concluded the following:

A. Electronic websites provide the ability of searching for information on current and potential customers.

B. Electronic websites include reports and clarifications about UAE companies.

C. Electronic websites provide a great opportunity for increasing the market share in the tourism sector.

4) Dad and Mas'oudah (2014): The role of the marketing communication elements in activating the tourist service - MA thesis, Kasdi Merbah Ouargla University

The study concluded that there is a positive impact for the marketing communication elements on activating the tourist service. It was also concluded that the direct marketing element plays an effective and distinguished role in the field of tourism marketing communication.

5) Khadija Sumaya ben Hido and Hani Hamed Al-Dmour (2011): The perceived image for Petra from the perspective of foreign tourists: The Jordanian Journal of Administrative Sciences Studies. 
The latter study concluded that the foreign tourists have a positive perceived mental image for Petra as a tourist destination. It was also concluded that the perceived mental image for Petra among the foreign tourists before visiting it is positive. This image became more positive after visiting it due to its archeological val ue. It was also concluded that tourists aren't satisfied in general about the quality of the hotel services provided to them in Petra. They aren't also satisfied about the transportation means inside Petra.

6) Marinko Jakoviljevic (2012) the role of public relations in the tourist destination marketing in Croatia.

The results showed that the promotion-mix elements play a significant positive role in attracting tourists to Croatia. However, the most influential element among such elements is the public relations. It was also concluded that the tourism pubic bodies spend about $38 \%$ of the promotional budget to matters related to public relations. As for the other promotion-mix elements, they can be arranged respectively according to their extent of influence as follows: direct marketing, advertisement, tourist publicity and sales promotion.

7) Michele Caroline (2013): Means of marketing communication that are applied by the travel and tourism agencies and trip organizers in the city of Jotun in South Africa.

It was concluded that those travel agencies apply the integrated marketing communications that are represented in direct marketing and positive word of mouth that can achieve positive results. Such positive can include attracting African tourists and other tourists to visit the city and enjoy it. Such positive results also include making the tourists stay for a longer period of time in the city which would lead them to spend more money. Spending more money shall lead to achieving economic benefits for the tourist city.

8) Dimitrios Buhalis (2000): Marketing the competitive destination of the future: (A theoretical study)Tourism Management Journal, University of Westminster

The study indicated that marketing the tourist destinations on the local, regional and international levels requires creating a balance in the strategic objectives of all stakeholders and the available resources in the tourist destination. Such a balance is required to achieve the intended sustainable tourism development.

\subsection{The Study's Results}

\section{First: Demographic Data}

Table 1. The respondents' demographic variables:

\begin{tabular}{|c|c|c|c|}
\hline Nationality & Frequency & Percentage \% & Rank \\
\hline American & 90 & 30 & $(1)$ \\
\hline British & 60 & 20 & (3) \\
\hline French & 70 & 23.3 & (2) \\
\hline German & 20 & 6.6 & (5) \\
\hline Canadian & 30 & 10.0 & (4) \\
\hline Italian & 30 & 10.0 & (4) \\
\hline \multicolumn{4}{|l|}{ Income } \\
\hline $1000 \overline{\text { USD or less }}$ & 50 & 16.7 & (4) \\
\hline $1001-2000$ USD & 70 & 23.3 & (3) \\
\hline $2001-3000$ USD & 80 & 26.7 & (2) \\
\hline More than 3000 USD & 100 & 33.3 & (1) \\
\hline \multicolumn{4}{|l|}{$\underline{\text { Age }}$} \\
\hline Less than 25 years & 60 & 20 & (4) \\
\hline $26-40$ years & 90 & 30 & (1) \\
\hline $41-55$ years & 80 & 26.7 & (2) \\
\hline 56 years or more & 70 & 23.7 & (3) \\
\hline
\end{tabular}

Based on table (1), it can be clear that the percentages of the nationalities of the foreign tourists visiting Jordanian destinations vary. The American nationality is ranked first (30\%), followed by the French nationality $(23.3 \%)$. As for the Canadian and Italian nationalities, they have similar percentages $(10 \%)$. As for the German nationality, it is ranked last $(6.6 \%)$.

As for income, the income of foreign tourists vary. Based on table (1), $60 \%$ of the income of the sampled foreign tourists is greater than 2000 USD / per month. That is considered a good indicator. As for the age of the sampled foreign tourists, $50 \%$ of them are in their $50 \mathrm{~s}$ and $60 \mathrm{~s}$. 
Second: The respondents'behavioral variables:

Table 2. The respondents' behavioral variables

\begin{tabular}{|c|c|c|c|}
\hline $\begin{array}{c}\text { The number of visits to the tourist } \\
\text { destination }\end{array}$ & Frequency & Percentage $\%$ & Rank \\
\hline The first time visit & 50 & 16.7 & (2) \\
\hline One time & 100 & 33.3 & (1) \\
\hline Twice & 100 & 33.3 & (1) \\
\hline Three times or more & 50 & 16.7 & (2) \\
\hline \multicolumn{4}{|l|}{ Desire to visit Jordan again } \\
\hline Yes & 200 & 66.6 & \\
\hline No & 20 & 6.6 & \\
\hline I don't know & 80 & 26.6 & \\
\hline Total & 300 & $\% 100$ & \\
\hline
\end{tabular}

Table (2) presents information related to the behavioral variables of the sampled foreign tourists. Such behavioral variables include the number of their visits to Jordan. For instance, $6.7 \%$ of the sample tourists are in their first time visit for Jordan. As for ones who have visited Jordan once or twice before, they include $66 \%$ of the sample. As for the ones who visited Jordan three times or more, they represent $16.7 \%$ of the sample. That is considered a good indicator because it means that there is a high demand for visiting the Jordanian tourist destinations by the foreign tourists.

Over than half of the sample $(66.6 \%)$ desire to return to Jordan again. That is considered a positive indicator that helps in attracting foreign tourists to visit Jordanian destination

\section{Third: The questionnaire's items that are related to the promotion-mix elements}

Based on table (3), it can be noticed that respondents' attitudes towards the Jordanian tourist's destinations are positive. That is because the grand mean is (3.650). This value is greater than the grand mean of the five point Likert scale (3). The difference between the two is a modest difference (0.650). Although the means of the questionnaire's statements vary, they are greater than the latter grand mean (which is 3 ).

The tourism promotion-mix element that is ranked first is advertisement through having an arithmetic mean of 3.770. It is greater than the grand mean with a difference of 0.770. In addition, the statement that got the highest mean states that the tourist had the opportunity to look at advertisement campaigns of various tourist destinations. This mean of this statement is (4.014) which is greater than the grand mean with a difference of one point.

The tourism promotion-mix element that is ranked second is personal selling with having a mean of 3.726. This value is greater than the grand mean with a difference of 0.770 . It is less than the mean of advertisement with a modest difference of 0.050 . This indicates that advertisement and personal selling play a significant role in attracting the foreign tourist towards tourist destinations.

The tourism promotion-mix element that is ranked third is public relations with having a mean of 3.710 . This value is greater than the grand mean with a difference of .710 .

The tourism promotion-mix element that is ranked fourth is sales promotion with having a mean of 3.630. This value is greater than the grand mean with a difference of 0.630 .

The tourism promotion-mix element that is ranked last is publicity with having a mean of 3.584 . This value is greater than the grand mean with a difference of 0.584 .

The questionnaire's statements as a whole are concerned with identifying the tourist's evaluations for the requirements of the tourist destinations. The respondents' evaluations for the five tourism promotion-mix elements are positive. The total arithmetic mean of all statements is 3.490. This value is greater than the grand mean with a difference of 0.490 . The difference is less than half a point and that is not a good indicator. However, the respondents' general satisfaction level is very good. To be specific, $86.6 \%$ of them are satisfied, whereas $10 \%$ of them aren't so and $3.3 \%$ are neutral. That can be illustrated through table (4). 
Table 3. The questionnaire's statements that are related to the promotion-mix elements

\begin{tabular}{|c|c|c|c|c|}
\hline No. & Statement & $\begin{array}{c}\text { arithmetic } \\
\text { mean }\end{array}$ & $\begin{array}{l}\text { Standard } \\
\text { deviation }\end{array}$ & Rank \\
\hline \multicolumn{5}{|c|}{ First: Advertisement } \\
\hline 1 & $\begin{array}{l}\text { You had the opportunity to look at advertisement campaigns of various tourist } \\
\text { destinations }\end{array}$ & 4.0140 & 1.1132 & \\
\hline 2 & $\begin{array}{l}\text { There are advertisement campaigns in Jordan that are launched by bodies that } \\
\text { are specialized in the field of tourism }\end{array}$ & 3.9161 & 1.4166 & \\
\hline 3 & $\begin{array}{l}\text { Advertisement campaigns make use of various means of advertisement (radio, } \\
\text { newspapers, journals, magazines, TV, cinema, tourist exhibition, etc...) }\end{array}$ & 3.7972 & 1.1661 & \\
\hline 4 & $\begin{array}{l}\text { The means of advertisement that transmit advertisements of tourist destinations } \\
\text { are characterized with being attractive and comprehensive }\end{array}$ & 3.7762 & 1.2185 & \\
\hline 5 & $\begin{array}{l}\text { The electronic means of advertisement - ( such as: mobiles, electronic websites, } \\
\text { and social networking sites - that transmit advertisements of tourist destinations } \\
\text { are characterized with being clear, accurate, and providing adequate information } \\
\text { about the foreign and Arab tourist destinations }\end{array}$ & 3.3497 & 1.2233 & $\begin{array}{l}(1) \\
3.770\end{array}$ \\
\hline \multicolumn{5}{|c|}{ Second: publicity } \\
\hline 6 & The tourist destinations provide modern and advanced promotional means & 3.6643 & 1.1745 & \\
\hline 7 & $\begin{array}{l}\text { The promotional messages and publications that I receive are free of any charges } \\
\text { and include adequate information about the tourist destinations }\end{array}$ & 3.4545 & 1.1815 & \\
\hline 8 & The promoters of promotional messages are very professional & 3.6294 & 1.0725 & \\
\hline 9 & $\begin{array}{l}\text { Promotional means - like brochures, and colored handbooks - make use of } \\
\text { persuasive techniques }\end{array}$ & 3.8182 & 1.1905 & \\
\hline 10 & $\begin{array}{l}\text { The authorities responsible for launching promotions on tourist destinations } \\
\text { make use of modern technological means in delivering the intended promotional } \\
\text { message }\end{array}$ & 3.3566 & 1.3130 & $\begin{array}{c}(5) \\
3.584\end{array}$ \\
\hline \multicolumn{5}{|c|}{ Third: Public relations } \\
\hline 11 & $\begin{array}{l}\text { The concerned authorities in the tourist destinations provide me with } \\
\text { information about the tourist services }\end{array}$ & 3.7762 & 1.0968 & \\
\hline 12 & $\begin{array}{l}\text { The workers working at the tourist destinations are keen to establishing friendly } \\
\text { relationships with the foreign tourists }\end{array}$ & 3.7832 & 1.1204 & \\
\hline 13 & $\begin{array}{l}\text { The workers working at the tourist destinations are keen to finding solutions for } \\
\text { solving the problems that we face }\end{array}$ & 3.5524 & 1.2485 & \\
\hline 14 & $\begin{array}{l}\text { The workers working at the tourist destinations are keen to identifying the } \\
\text { desires and needs of tourists }\end{array}$ & 3.9231 & 1.0419 & \\
\hline 15 & $\begin{array}{l}\text { The workers working at the tourist destinations are keen to establishing long-term } \\
\text { relationships with the foreign tourists and making them stay longer }\end{array}$ & 3.5175 & 1.1435 & $\begin{array}{l}(3) \\
3.710\end{array}$ \\
\hline \multicolumn{5}{|c|}{ Fourth: Personal selling } \\
\hline 16 & $\begin{array}{l}\text { The workers working at tourism destinations have adequate experience in the } \\
\text { field of their tourism related work }\end{array}$ & 3.5874 & 1.1708 & \\
\hline 17 & The workers working in the regions I have visited in Jordan meet my demands & 3.4545 & 1.2317 & \\
\hline 18 & $\begin{array}{l}\text { Workers have the ability of persuading fore ign tourists and can establish friendly } \\
\text { relationships with them }\end{array}$ & 3.8182 & 1.1298 & \\
\hline 19 & Workers have courtesy, decency and politeness when dealing with me & 3.7762 & 1.2470 & \\
\hline 20 & $\begin{array}{l}\text { Workers are highly professional in dealing with foreign tourists, solving the ir } \\
\text { problems and making them feel satisfied }\end{array}$ & 3.9720 & 1.1255 & $\begin{array}{l}(2) \\
3.721\end{array}$ \\
\hline \multicolumn{5}{|c|}{ Fifth: Sales promotion } \\
\hline 21 & The officials responsible for tourism promotion give foreign tourists souvenirs & 3.9720 & 1.0611 & \\
\hline 22 & $\begin{array}{l}\text { There are good offers and discounts on the prices of accommodations, trips and } \\
\text { entertainment services }\end{array}$ & 3.5664 & 1.2591 & \\
\hline 23 & $\begin{array}{l}\text { Promoters are keen to providing the necessary supplies that enable tourists to see } \\
\text { the tourist site in the tourist destination }\end{array}$ & 3.3566 & 1.4261 & \\
\hline 24 & Through my visit, I have acquired a good beautiful experience & 3.5175 & 1.2094 & \\
\hline 25 & $\begin{array}{l}\text { The visit program includes holding seminars and meetings about guiding and } \\
\text { cultural matter }\end{array}$ & 3.7413 & 1.1969 & $\begin{array}{c}(4) \\
3.630\end{array}$ \\
\hline \multicolumn{5}{|c|}{ Sixth: Tourists'mental image } \\
\hline 26 & $\begin{array}{l}\text { The present tourist destination has requirements of tourist attraction and are } \\
\text { better than I expected. This destination is characterised wit being authentic and } \\
\text { unique }\end{array}$ & 3.4895 & 1.0405 & \\
\hline 27 & $\begin{array}{l}\text { I shall advise my colleagues, friends, relatives and family members to visit the } \\
\text { tourist destination that I have visited this year }\end{array}$ & 3.5315 & 1.0733 & \\
\hline 28 & $\begin{array}{l}\text { The workers working in the field of touris } m \text { are keen to providing services of } \\
\text { good quality in the tourist destination }\end{array}$ & 3.6573 & 1.0818 & \\
\hline 29 & The prices of the services I received during this visit are reasonable and suitable & 3.3566 & 1.1652 & \\
\hline 30 & $\begin{array}{l}\text { In case I re-visited the present tourist destination, I shall stay in the same hotel I } \\
\text { am staying in currently and deal with the same travel and tourism agency. }\end{array}$ & 3.4196 & 1.1408 & $\begin{array}{c}(6) \\
3.490 \\
\end{array}$ \\
\hline
\end{tabular}

*Grand mean $=$ Sum of the statements' means $/ 30=3.650$ 
Table 4. Respondents'satisfaction level

\begin{tabular}{cccc}
\hline $\begin{array}{c}\text { Respondents's atisfaction level about the tourist } \\
\text { destination }\end{array}$ & & & \\
\hline $\begin{array}{c}\text { Satisfied } \\
260\end{array}$ & Neutral & Not satisfied & Total \\
86.66 & 30 & 30 & 300 \\
& 3.33 & 10.0 & $100 \%$ \\
\hline
\end{tabular}

\section{Testing the first hypothesis:}

There isn't any statistically significant relationship at the significance level $0.05 \geq$ a between the tourism promotion-mix elements as a whole - which are represented in advertisement, publicity, public relations, personal selling, and sales promotion - and the foreign tourists' mental images of the Jordanian tourist destinations

In order to test the above hypothesis, the researcher conducted a multi-regression analysis between the tourism promotion-mix element and the foreign tourists' mental images of the Jordanian tourist destinations. The results of this analysis can be presented in table (5):

Table 5. Results of testing the first hypothesis and its sub-hypotheses

\begin{tabular}{|c|c|c|c|c|c|c|c|c|}
\hline Hypothesis & $\boldsymbol{r}$ & $\begin{array}{c}\text { coefficient of } \\
\text { determination }\end{array}$ & $\begin{array}{c}\text { Calculated } \\
\text { F }\end{array}$ & $\begin{array}{c}\text { Tabulated } \\
\text { F }\end{array}$ & $\begin{array}{c}\text { Regression } \\
\text { coefficient }\end{array}$ & $\begin{array}{l}\text { Degree } \\
\text { of } \\
\text { freedom } \\
\text { (df) }\end{array}$ & Sig. & $\begin{array}{l}\text { Result of } \\
\text { the } \\
\text { hypothesis } \\
\text { test }\end{array}$ \\
\hline F1promotion-mix & 0.874 & 0.763 & 148.324 & 2.01 & 0.000 & $\begin{array}{l}5 \backslash 294 \\
1299\end{array}$ & 0.159 & Rejected \\
\hline F1.1Advertising & 0.688 & 0.474 & 17.181 & 1.96 & 0.122 & $\begin{array}{l}1 / 298 / \\
299\end{array}$ & 0.00 & Rejected \\
\hline F1.2public ity & 0.641 & 0.411 & 15.136 & 1.96 & 0.131 & $\begin{array}{l}1 / 298 / \\
299\end{array}$ & 0.000 & Rejected \\
\hline F1.3 PR. & 0.616 & 0.379 & 14.163 & 0.96 & 0.103 & $\begin{array}{l}1 / 298 / \\
299\end{array}$ & 0.000 & Rejected \\
\hline $\begin{array}{l}\text { F1.4Personal } \\
\text { Selling }\end{array}$ & 0.648 & 0.420 & 15.412 & 1.96 & 0.167 & $\begin{array}{l}1 / 298 / \\
299\end{array}$ & 0.000 & Rejected \\
\hline $\begin{array}{l}\text { F1.5Sales } \\
\text { Promotion }\end{array}$ & 0.539 & 0.291 & 11.598 & 1.96 & 0.089 & $\begin{array}{l}1 / 298 / \\
299\end{array}$ & 0.000 & Rejected \\
\hline
\end{tabular}

Table (5) presents the results of testing the first hypothesis and its sub-hypotheses. It can be noticed that all of those hypothesis are rejected. That is because all of the tourism promotion-mix elements have an impact on the foreign tourists' mental image of the Jordanian tourist destinations. Such elements can interpret $76.3 \%$ of the changes that occur in that image.

The extent of those elements' influence vary. For instance, advertisement is ranked first in relation to its extent of influence and can interpret $47.4 \%$ of the changes that occur in the aforementioned image. It is followed by personal selling (42.0\%). Publicity is ranked third (41.1\%) and public relations is ranked fourth $(37.9 \%)$. As for the sale promotion element, it is the least influential element and it is ranked last. The latter element can interpret $29.1 \%$ of the changes that occur in the aforementioned image.

Through table (5), it can be noticed that the calculated $\mathrm{F}$ value is greater than the tabulated $\mathrm{F}$ value at the significance level of $(0.5 \geq \mathrm{a})$. Based on that, all the aforementioned null hypotheses are rejected and the alternative hypothesis is accepted. Thus, the following can be concluded:

There is a statistically significant relationship at the significance level $0.05 \geq$ a between the tourism promotion-mix elements and the foreign tourists'mental images of the Jordanian tourist destinations

\section{Testing the second hypothesis:}

There isn't any statistically significant difference - at the significance level $0.05 \geq \mathrm{a}$ - between the extent of influence of the tourism promotion-mix elements on the foreign tourists' mental images of the Jordanian tourist destinations which can be attributed to their nationality 
Table 6. Results of testing the second hypothesis

\begin{tabular}{ccccc}
\hline $\begin{array}{c}\text { The foreign touris ts' mental } \\
\text { images }\end{array}$ & arithmetic mean & Standard deviation & Calculated F & Sig. \\
\hline American & 4.120 & 0.512 & 2.661 & 0.330 \\
British & 3.980 & 0.481 & \\
French & 3.880 & 0.446 & \\
German & 3.320 & 0.383 & \\
Canadian & 3.512 & 0.388 & & \\
Italian & 3.467 & 0.422 & & \\
\hline
\end{tabular}

One way analysis of variance (ANOVA) was conducted to test hypothesis (2). It was concluded to identify any statistically significant difference - at the significance level $0.05 \geq \mathrm{a}$ - between the extent of influence of the tourism promotion-mix elements on the foreign tourists' mental images of the Jordanian tourist destinations which can be attributed to their nationality. The calculated F value is 2.661 and the probability level is 0.330 which is greater than the significance level $0.05 \geq \mathrm{a}$. Thus, the second hypothesis is accepted the following can be concluded:

There isn't any statistically significant difference - at the significance level $0.05 \geq \mathrm{a}$ - between the extent of influence of the tourism promotion-mix elements on the foreign tourists' mental images of the Jordanian tourist destinations which can be attributed to their nationality

\section{Conclusion and Recommendations}

\subsection{Conclusion}

Based on the aforementioned, the researchers of the current study have concluded the following:

1) The sampled foreign tourists have positive towards the Jordanian tourist destinations. That is concluded through having a grand mean of 3.650 which is greater than the grand mean of the five point Likert scale (3). The difference between the two is a modest difference $(0.650)$.

2) The sampled foreign tourists show a high level of satisfaction about the Jordanian tourist destinations. For instance, $86.66 \%$ of the respondents are satisfied about the services they received during their visit to Jordan

3) The hypotheses tests show that all the tourism promotion-mix elements have statistically significant impact on the foreign tourists' mental images of the Jordanian tourist destinations

4) The extent of influence of the tourism promotion-mix elements on the foreign tourists' mental images of the Jordanian tourist destinations vary. The most influential element is advertisement (47.4\%) followed by personal selling. The least influential element is the sale promotion $(29.1 \%)$

5) The results show that the variable of nationality doesn't have any impact on the foreign tourists' mental images of the Jordanian tourist destinations

\subsection{Recommendations}

In the light of the aforementioned results, the researchers of the present study suggested several recommendations. Such recommendations shall participate in promoting tourism related awareness among people, especially about the tourism promotion-mix elements. Spreading such awareness shall participate in achieving the optimal utilization of such elements as one integral unit. That is because those elements can be utilized through using an integral communication system. These recommendations are the following:

1) Promoting tourist destinations requires using several languages, such as: Arabic, English, French, and Italian. That should be done in order to achieve the greatest possible numbers of benefits from the local, Arab and foreign sectors.

2) Making tourism exhibitions to present tourism related photos, and movies about the availability of the tourism attraction requirements in the Jordanian tourist destinations.

3) Launching extensive promotional campaigns through social networking sites, such as: Facebook, Twitter, and electronic websites.

4) Cooperating with Arab and foreign tourism agencies for exchanging promotions and achieving mutual benefits for Jordan, and Arab and foreign countries.

5) Launching programed persuasive tourism advertisements about the Jordanian tourist destinations that are known on the global level. Such destinations may include: Petra, Jarash, the Dead Sea, Al-Maghtas 
(the Baptism site), and Wadi Ram. Such advertisements should be launched by the Jordanian Ministry of Tourism and Antiquities, Jordan Tourism Board and international airline companies.

6) Setting an integrated promotional strategy that involves formal and informal media channels. The researchers also recommended publishing the greatest possible amount of detailed information about the Jordanian tourist destinations.

\section{References}

Al-Hadid, M., \& Al-Shunaq, R. (2013). The impact of the electronic marketing mix on tourists' attitudes towards tourism in Jordan. The Journal of Administrative Sciences Studies, 40(2). 2013

Al-Rabi'a (2007). The impact of using internet on promoting tourism in the United Arab Emirates (UAE), (Unpublished) MA thesis, Amman Arab University

Al-taee, H. (2012). Marketing for hospitality industry, Al.yazoori, Ammanjordan.

Al-taee, H., \& Ahmed. (2010). Integrated communication-mix, Al.yazoori, Amman, Jordan.

Annamira, S. D., Elena, B., \& Laura, D. (2017), Social representations of the European Capitals and destination e-branding via multi - channel web communication, Journal of Destination Marketing and Management.

Brees, A., \& Al-Hamiri, B. (2014). The impact of the promotional-mix of tourist services on achieving satisfaction among tourists, University of Karbula', Journal of Tourism Studies, Iraq.

Dad and Mas'oudah (2014). The role of the marketing communication elements in activating the tourist serviceMA thesis, Kasdi Merbah Ouargla University Algeria Jordan Tourism Board / Data of 2016

Dimitrios, B. (2000). Marketing the competitive destination of the future tourism, management journal, University of westerin-ster.

How to achieve an effective Promotion -Mix www.cim.co.uklmarketingresources. The charted Institute of Marketing. irect Marketing - The Direct Marketing Association (DMA) at www.the-dma-org.

Khadija, S. H., \& Hani, H. A. (2011). The perceived image for Petra from the perspective of foreign tourists. The Jordanian Journal of Administrative Sciences Studies, 38(1), 2011.

Kotler, P. B., \& Makens (2014). Marketing for Hospitality and Tourism, Pearson. Ministry of Tourism and Antiquities Jordan, 2016.

Markino, J. (2012). The Role of public Relations in the Marketing of Tourist Destinations in Croatia, (tzo-fuzine@rit-comhr).

Michele, C. M. (2013). Marketing Communication Methods used by tour operators in Gauteng. Master of Commerce, University of South Africa.

Saritha, P. (2013). 4 most Important Elements of Promotion Mix- Business Marketing.

Schmoll, G. (2010). Tourism Promotion, London: Tourism International Press.

Vochen, L. P. (2013). Essential of services marketing, Pearson.

William, E. G. (2002), Tourism development principles, processes and policies. John Wiley \&Sons, INC, NY.

WTO. World tourism organization, annual report, Madrid, 2017.

Yeamduan, N., Rosa, M., \& CJavier, S. G. (2017). The influence of Social media in creating expectations. An empirical study for tourist destination. Journal of Tourism Research, 65, 60-70.

\section{Copyrights}

Copyright for this article is retained by the author(s), with first publication rights granted to the journal.

This is an open-access article distributed under the terms and conditions of the Creative Commons Attribution license (http://creativecommons.org/licenses/by/4.0/). 